\title{
MANAJEMEN DAKWAH HALAQAH DALAM PEMBERDAYAAN MASYARAKAT BORNEO MELALUI KHATULISTIWA BERBAGI
}

\author{
Patmawati \\ Fakultas Ushuluddin, Adab dan Dakwah (FUAD) IAIN Pontianak \\ Email: fwati1974@gmail.com
}

Diterima Tangal: 30 April 2019

Selesai Tanggal 22 Mei 2019

\begin{abstract}
Dakwah Management of the Halaqah Khatulistiwa Berbagi is a dakwah activity in a systematic and coordinative manner that starts from planning, organizing, implementing, monitoring and evaluating da'wah activities. Khatulistiwa Berbagi activities are engaged in the field of education by establishing an informal Equator Sharing school. The research method used is qualitative research. Data collected through literature and field studies through observation, participant observation, and interviews. Analysis of the data used an interpretive approach. The focus of this study is how do the Dakwah Management of the Halaqah Khatulistiwa Berbagi? How does the Dakwah Halaqah of Khatulistiwa Berbagi share? Who are the Khatulistiwa Berbagi's partners? The results of the study illustrate that the management of the Halaqah Da'wah Khatulistiwa Berbagi has applied modern management as seen from the placement of Human Resources in accordance with their respective expertise there has been a clear division of tasks among the administrators and teachers. Da'wah is done by grouping students according to their level of education. Dakwah Khatulistiwa Berbagi's partners are Munzalan Mubarakan, IAIN Pontianak, STAN, and Pontianak City Health Office.
\end{abstract}

[Manajemen dakwah halaqah Khatulistiwa Berbagi adalah suatu kegiatan dakwah yang dilaksanakan oleh Khatulistiwa Berbagi secara sistematis dan koordinatif yang dimulai dari perencanaan, pengorganisasian, pelaksanaan, pengawasan dan evaluasi kegiatan dakwah. Kegiatan dakwah Khatulistiwa Berbagi bergerak dalam bidang pendidikan dengan mendirikan sekolah informal Khatulistiwa Berbagi. Metode penelitian yang digunakan adalah penelitian kualitatif. Pengumpulan data melalui studi pustaka dan lapangan melalui pengamatan, observasi partisipan, dan wawancara. Analisa yang digunakan dengan pendekatan interpretif. Adapun fokus dalam penelitian ini adalah bagaimanakah manajemen dakwah halaqah Khatulistiwa Berbagi? Bagaimanakah dakwah halaqah Khatulistiwa berbagi? Siapa sajakah mitra dakwah Khatulistiwa Berbagi? Hasil penelitian menggambarkan bahwa manajemen dakwah halaqah Khatulistiwa Berbagi sudah menerapkan manajemen modern yang terlihat dari penempatan SDM sesuai dengan keahlian masing-masing, sudah ada pembagian tugas yang jelas di antara pengurus dan guru-guru. Dakwah halaqah dilakukan dengan cara mengelompokkan peserta didik sesuai dengan tingkat pendidikan. Mitra dakwah Khatulistiwa Berbagi adalah Munzalan Mubarakan, IAIN Pontianak, STAN, dan Dinas Kesehatan Kota Pontianak].

Kata Kunci: Manajemen Dakwah, halaqah, Khatulistiwa Berbagi 


\section{PENDAHULUAN}

Manajemen dakwah adalah sebuah upaya untuk memberi arah peradaban dan perubahan dimensi kehidupan manusia dan masyarakat secara transformatif menuju kesejahteraan hidup duniawi yang islami. Gerakan dakwah halaqah menjawab berbagai persoalan pengiring yang muncul dalam masyarakat global-industrial. Berbagai persoalan tersebut berkaitan dengan tumbuhnya kawasan perumahan dan Industri, perilaku dan tatanan sosial-budaya yang belum diketemukan rujukannya dalam pemikiran klasik, munculnya kelompok strategis baru (kelas menengah, generasi muda terdidik, profesional muda, politisi, birokrat, dan intelektual), kemiskinan material dan spiritual, perluasan keterasingan dan penyimpangan sosial serta keagamaan, dan perluasan kaum pekerja buruh ${ }^{1}$.

Khatulistiwa Berbagi berkonsentrasi di sektor pendidikan informal karena dalam konteks pendidikan ternyata belum mendapat perhatian yang serius di Indonesia. Padahal pendidikan informal, dalam konteks sejarah merupakan sistem

\footnotetext{
${ }^{1}$ Muhlm. Ishaq Samad, 2013, "Manajemen Dakwah Jejaring Dalam Pemberdayaan Masyarakat: Studi Manajemen Networking Learning Assistance Program For Islamic School (LAPIS)", dalam Jurnal Diskursus Islam, vol. 1, no. 1, April, Program Pascasarjana UIN Alauddin Makassar, hlm. 1-2.
}

pendidikan tertua di Indonesia, tetapi pada kenyataannya, masih terdapat banyak kelemahan dalam berbagai sisi seperti manajemen, sumber daya manusia, dan sarana/prasarana. Hal ini menyebabkan menurunnya kualitas pendidikan, utamanya pendidikan usia dini, dasar dan menengah dan berdampak pada kualitas anak didik. Padahal dalam undang-undang sistem pendidikan nasional, secara jelas menyebutkan bahwa sekolah informal merupakan bagian yang tak terpisahkan dari sistem pendidikan nasional. Konsekuensinya adalah setiap upaya peningkatan kualitas pendidikan usia dini, dasar dan menengah di Indonesia harus mengikutsertakan subsektor pendidikan informal.

Untuk itu, dalam penelitian ini akan dipaparkan manajemen dakwah Khatulistiwa Berbagi dalam membantu masyarakat melalui sub-sektor pendidikan informal dengan menggunakan halaqah (kelompok) sejak berdiri Desember 2013 sampai sekarang. Tulisan ini menarik dengan menjadikan Khatulistiwa Berbagi sebagai obyek penelitian, sebab Khatulistiwa Berbagi terbentuk atas inisiatif anak muda yang bernama Anggia Angraini yang berhasil mengajak teman-temannya dari berbagai universitas untuk bergabung, dan 
mendirikan sekolah informal dengan nama Khatulistiwa Berbagi. Khatulistiwa Berbagi merupakan sekolah informal yang independen (mandiri) dalam membantu anak-anak dari kelas ekonomi menengah ke bawah atau sering disebut sebagai masyarakat marginal. Sebagaimana dituturkan oleh Agus Setiawan bahwa masyarakat marginal adalah masyarakat kelas bawah yang terpinggirkan secara ekonomi, pendidikan, kesehatan dan sosial dari kehidupan masyarakat di daerah perkotaan. ${ }^{2}$

Aktivitas dakwah seperti tersebut di atas, sangat menarik untuk ditelusuri, terutama terkait dengan kemampuan Khatulistiwa Berbagi untuk tetap eksis dengan manajemen dakwah halaqah dalam memberdayakan masyarakat Borneo. Oleh karena itu dalam penelitian ini akan memaparkan bagaimanakah manajemen dakwah Khatulistiwa Berbagi? Bagaimanakah dakwah halaqah Khatulistiwa Berbagi? Siapa sajakah mitra dakwah Khatulistiwa Berbagi?

2 Soiman, 2017, "Dakwah Islam Untuk Masyarakat Marjinal Perkotaan" dalam Prosiding Seminar Nasional Manajemen Dakwah IAIN Pontianak dengan tema Revitalisasi Dakwah Pinggiran: Penguatan Profesionalitas Dai Infrastruktur Dakwah, Pontianak: IAIN Pontianak Press., hlm. 3.

\section{METODE PENELITIAN}

Teknik pengumpulan data dalam penelitian ini dilakukan melalui studi kepustakaan dan pengumpulan data di lapangan yang menitikberatkan pada observasi partisipan. Metode ini dianggap cukup baik untuk mengetahui kegiatan yang dilakukan oleh Khatulistiwa Berbagi dalam memberdayakan masyarakat Borneo khususnya anak-anak usia sekolah. Observasi ini dilakukan di sekolah TK Pertiwi di jalan Untung Suropati sebagai lokasi kegiatan belajar mengajar sekolah informal Khatulistiwa Berbagi.

Dalam melakukan observasi partisipan, peneliti juga melibatkan mahasiswa jurusan Bimbingan Konseling Islam (BKI) dan jurusan Manajemen Dakwah (MD) Fakultas Usuluddin Adab dan Dakwah yang mengambil mata kuliah Manajemen Dakwah dan Perencanaan Dakwah, dimana peneliti adalah pengampu mata kuliah tersebut. Hal ini peneliti lakukan dalam rangka mahasiswa tidak hanya berkutak-katik dengan teori semata tetapi langsung ke lapangan, menyaksikan manajemen yang diterapkan oleh pendiri dan pengurus Khatulistiwa Berbagi yang notabenenya adalah mahasiswa juga.

Selain kedua teknik tersebut, wawancara menjadi metode utama dalam 
pengumpulan data. Semua data dikumpulkan dengan cara wawancara langsung secara intensif dengan para informan. Informan terdiri dari pendiri Khatulistiwa Berbagi, pengurus, anak-anak yang belajar di Khatulistiwa Berbagi, orang tua anak-anak dan masyarakat. Peneliti juga mendapatkan data dari laporan mahasiswa.

Penentuan informan dilakukan berdasarkan system snow-balling. Sebagai informan kunci, peneliti memilih pendiri Khatulistiwa Berbagi karena dialah pelaku berdirinya sekolah informal ini. Dari pendiri tersebut, wawancara dilakukan terhadap pengurus-pengurus lain yang memahami sejarah berdirinya dan ikut terlibat langsung di Khatulistiwa Berbagi. Wawancara juga dilakukan terhadap anak-anak dengan mempertimbangkan bahwa merekalah yang merasakan manfaat dari keberadaan sekolah informal Khatulistiwa Berbagi ini. Semua data hasil wawancara dan pengamatan lapangan sehari-hari dicatat dengan cermat dan serinci mungkin serta dikumpulkan sehingga menjadi catatan lapangan atau fieldnotes.

Adapun studi kepustakaan digunakan untuk menjelaskan hal-hal yang berhubungan dengan teori dan fakta lapangan yang telah dilakukan oleh peneliti sebelumnya. Metode ini juga digunakan untuk menelusuri penelitian yang serupa, penelitian yang membahas tentang halaqah sebagai metode dalam melaksanakan dakwah.

Untuk menjamin validitas data dan menghindari tercecernya data, digunakan alat perekam kamera digital untuk mengabadikan peristiwa-peristiwa yang erat kaitannya dengan manajemen dakwah halaqah Khatulistiwa Berbagi dalam memberdayakan masyarakat Borneo melalui pendidikan anak-anak dari kalangan keluarga menengah kebawah. Masalah pendidikan adalah masalah krusial yang memerlukan penanganan yang serius, jika permsalahan ini tidak segera ditangani maka dikhawatirkan akan menimbulkan masalah baru. $^{3}$

Analisis yang dilakukan dalam penelitian ini menitikberatkan pada pendekatan interpretif dan bukan merupakan sebuah ilmu eksperimental untuk mencari hukum, ${ }^{4}$ melainkan sebuah ilmu yang interpretif untuk mencari sebuah kejelasan

\footnotetext{
3 Jauhar Fuad dkk., 2014, "Pemberdayaan Anak Jalanan Berbasis Musala di Kabupaten Ngadirejo Kota Kediri, dalam Kompilasi Hasil Penelitian Aksi Partisipatoris, Zidal Huda (penyusun), Jakarta: Direktorat Perguruan Tinggi Islam, Direktorat Jenderal Pendidikan Islam dan Kementerian Agama RI., hlm. 69.

${ }^{4}$ Zuly Qodir, 2015, “ Kontestasi Penyiaran Agama di Ruang Publik: Relasi Kristen dan Islam di Kota Jayapura", dalam jurnal Harmoni Vol.14 no. 1 Januari-April, hlm. 42.
} 
hasil penelitian. ${ }^{5}$ Dengan demikian, diuraikan dan dijelaskan lebih jauh mengenai manajemen dakwah, dakwah halaqah, pemberdayaan masyarakat dan Khatulistiwa Berbagi.

\section{HASIL DAN PEMBAHASAN}

\section{Sekilas Khatulistiwa Berbagi}

Khatulistiwa Berbagi berdiri pada bulan Desember tahun 2013 yang diprakarsai oleh Anggia Angraeni. Lokasi Khatulistiwa Berbagi di jalan Untung Suropati. Strata sosial di masyarakat, ada kelas atas yang dibuktikan dengan rumahrumah mewah dan ada juga kelas bawah dikenal dengan nama Kampung Pemulung Waduk Permai. Dahulu, di kawasan ini ada sebuah waduk besar, dimana pemukiman para pemulung persis di pinggiran waduk bagian barat. Sedangkan di tepi sebelah timur waduk berdiri megah sebuah hotel bintang empat. Sejak tahun 2000 an, waduk ini ditutup dan digantikan dengan pembangunan ruko dan sentra ekonomi lainnya hingga menutupi sebagian besar kawasan bekas waduk sebelah utaranya. Sedangkan sebelah utara pemukiman berderet bangunan komplek perumahan

\footnotetext{
5 Deddy Mulyana, 2008, Metodologi Penelitian Kualitatif Paradigma Baru Ilmu Komunikasi dan Ilmu Sosial Lainnya, Bandung: Remaja Rosdakarya, hlm. 168.
}

mewah. Anehnya, kampung pemulung yang berada diantara bangunan mewah di sekitar kawasan waduk itu tetap ada dan dibiarkan begitu saja tampa satu kebijakan pembangunan yang berarti.

Kondisi di atas memperlihatkan perkembangan ekonomi yang membawa adanya dua pihak yakni pihak pertama, pihak swasta domestik dan asing yang bermodal kuat mampu mendirikan berbagai jenis produksi dalam skala besar, teknologi canggih, efesiensi tinggi, kualitas produksi meningkat, dan keuntungan yang diperoleh besar. Pihak kedua, sektor-sektor ekonomi yang menyangkut rakyat makin melemah, terutama sektor informal. Kerajinan rumah tangga, industry kecil, transfortasi non mesin sebagian besar bangkrut. Fenomena yang ironi terlihat, yang besar makin kuat sementara yang kecil semakin lumpuh atau mati. ${ }^{6}$ Akhirnya akan membawa tontonan kepada kita semua masyarakat yang terpecah-belah berdasarkan materi. ${ }^{7}$

Pihak kedualah yang berada dalam kondisi pemukiman yang kumuh, dengan iklim sosial masyarakat yang terbelakang, memberikan pemandangan yang sangat berbeda (kontras) dengan gedung ruko, hotel

\footnotetext{
${ }^{6}$ Samsul Munir Amin, 2009, Ilmu Dakwah, Jakarta: Amzah, hlm. 296.

${ }^{7}$ Alvin Toffler, 1989, Kejutan Masa Depan, Jakarta: Pantja Simpati, hlm. 269.
} 
berbintang, serta komplek pemukiman mewah yang mengelilingi. Tidak adanya pasilitas pendidikan, kesehatan dan ibadah yang refresentatif bagi anak-anak para pemulung di kawasan ini (baik aksessibilitas dan biaya) semakin mempertegas ketertinggalan dan keterbelakangan mereka di tengah himpitan pembangunan kota. Karena kekurangan ekonomi, banyak dari anak-anak usia sekolah yang tidak dapat menikmati layanan pendidikan yang wajar. Puluhan tahun mereka hidup di kawasan itu, menggantungkan diri hidup dengan memungut sampah, seolah menjadi "takdir" yang harus mereka jalani secara turun temurun, dan diwarisi dari generasi ke generasi. $^{8}$

Di tengah semua keprihatinan ini, Anggia Angraeni terpanggil untuk mengajari anak-anak pemulung di perkampungn pemulung Waduk Permai. Dia merangkul anak-anak yang kurang mampu dari segi ekonomi, pendidikan rendah, dan kurang mendapat perhatian dari orang tua. Kondisi seperti ini berdampak pada masa depan anak-anak yang suram. Dia mulai mendekati anak-anak tersebut, dan bergaul dengan mereka, sehingga Anggi dianggap sebagai

8 Patmawati dkk., 2017, "Penggunaan Wasilah Dakwah Terhadap Anak-anak Pemulung Waduk Permai", dalam jurnal Al-Hikmah, Vol. XI Edisi 2, Desember, hlm. 205. kakak mereka. Dalam proses pembelajaran anak-anak tetap memanggil mereka semua para guru di Khatulistiwa Berbagi dengan panggilan kakak.

Anggia Angraeni mengajari anakanak di teras rumah warga dengan berpindah-pindah, selama kurang lebih 4 bulan. kegiatannya ini disorot oleh media lokal Pontianak. Sejak itu, anak-anak muda khususnya kalangan mahasiswa menawarkan diri untuk turut membantu mengajar. Selaras dengan seleksi alam, sekarang pengajar tetap ada 10 orang dan 4 orang volunteer, mereka ini dapat kita sebut kalangan anak muda terdidik. Murid mereka sudah ada 80 orang.

Jumlah murid yang banyak membuat teras warga tak mampu lagi menampung mereka. di tengah kondisi seperti ini ada seorang ibu yang bernama Sari Mahmud Leni memfasilitasi pertemuan antara Anggia dkk menemui ibu Sekertaris Daerah (Sekda) Provinsi Kalimantan Barat (Ratna Yuniar). Dia mengizinkan Khatulistiwa Berbagi menggunakan Rumah Dinas di Komplek TK Pertiwi 2 di jalan Untung Suropati (wawancara dengan Anggia Angraeni, Selasa 24 Maret 2015 dan Laporan Mahasiswa BKI dan MD). 
Adapun struktur organisasi sekolah informal Khatulistiwa Berbagi:

$\begin{array}{ll}\text { Ketua } & \text { : Anggia Angraeni } \\ \text { Wakil } & \text { : Triono Siswahyudi } \\ \text { Sekretaris } & \text { : Sami Darianto } \\ \text { Bendahara } & \text { : Dia Ayu L } \\ & \text { Norma Juwita } \\ \text { Inventaris } & \text { : Zeni Prabowo } \\ & \text { Vivin } \\ \text { Pendidikan } & \text { : Dwi Bintang } \\ \text { Humas } & \text { : Winda } \\ & \text { Anggita }\end{array}$

(Sumber: Wawancara, Selasa 23 Maret 2015)

Para pengurus ini berasal dari berbagai perguruan tinggi di antaranya Universitas Tanjungpura, Universitas Muhammadiyah Pontianak, Sekolah Tinggi Manajemen Informatika dan Komputer, Akademi Kebidanan Aisiyah dan lain-lain. Mereka tidak ada yang berlatarbelakang pendidikan dan agama tetapi mereka menyadari bahwa maju tidaknya suatu bangsa tergantung dari pendidikan yang diperoleh masyarakatnya.

\section{Manajemen Dakwah Khatulistiwa Berbagi}

Manajemen dakwah Khatulistiwa Berbagi adalah sebuah kegiatan atau aktivitas dakwah yang dilaksanakan secara sistematis dan koordinatif yang dimulai dari sebelum pelaksanaan sampai akhir dari pelaksanaan sebuah kegiatan dakwah. Kegiatan dakwahnya dimulai dari perencanaan kegiatan dakwah, kemudian pengorganisasian kegiatan dakwah, pelaksanaan kegiatan dakwah, pengawasan dari kegiatan dakwah dan terakhir adalah evaluasi kegiatan dakwah tersebut.

Seluruh kegiatan dakwah mengarah pada visi dan misi Khatulistiwa Berbagi. Adapun visi dan misinya yakni: anak-anak yang tergabung di Khatulistiwa Berbagi bisa mendapatkan pendidikan yang layak sehingga tidak ada lagi diskriminasi di dunia pendidikan. Mereka ingin berbagi rasa dengan anak-anak baik suka maupun duka untuk meraih mimpi mewujudkan anak-anak Pontianak yang cerdas, bisa bersaing dan memiliki mental yang tangguh serta selalu beriman dan bertaqwa kepada Tuhan Yang Maha Esa. Dari visi dan misi inilah maka sekolah informal diberi nama Khatulistiwa Berbagi. Khatulistiwa Berbagi tidak lain dan tidak bukan hanyalah untuk saling berbagi. Baik dari segi ilmu pengetahuan serta pengalaman kepada anak-anak. Mereka memberi penekanan pada akhir visi dan misinya bahwa anak-anak adalah makhluk 
Tuhan ${ }^{9}$ sehingga mereka wajib beriman dan bertakwa kepada pencipta-Nya. Mereka juga mengharapkan anak-anak yang kurang mampu dari segi perekonomian untuk sekolah dan mendapatkan pendidikan layaknya seperti kakak-kakak yang sampai ke jenjang universitas bahkan melampaui tingkat pendidikan mereka. ${ }^{10}$

Perencanaan dakwah Khatulistiwa Berbagi melalui kegiatan pendidikan informal yang meliputi pendidikan umum, pendidikan agama dan pendidikan karakter. Khatulistiwa Berbagi melaksanakan program yang fleksibel untuk membantu masyarakat menengah ke bawah dalam menyelesaikan masalah-masalah pendidikan. Misi ini direalisasikan dengan programprogram dan aktifitas-aktifitas edukasi yang fleksibel dan memperhatikan kebutuhan peserta didik.

Khatulistiwa Berbagi merupakan program bantuan pembelajaran bagi anakanak tingkat Taman Kanak-kanak, sekolah dasar dan menengah pertama. Melalui Khatulistiwa Berbagi, isu-isu kualitas pendidikan di tingkat usia dini, dasar dan menengah pertama dapat diselesaikan

9 Harjani Hefni, 2014, Komunikasi Islam, Pontianak: IAIN Pontianak Press, hlm. 54.

10 Laporan tugas mata kuliah Manajemen Dakwah jurusan Bimbingan Konseling Islam semester IV tahun 2015. melalui berbagai program. Adapun jadwal kegiatan belajar mengajar di Khatulistiwa Berbagi sebagai berikut: selasa dan kamis mata pelajaran alfabeth dan matematika, jumat pelajaran agama, sabtu kerja bakti dan permainan. Permainan dilakukan di halaman sekolah. Salah satu permainan yang dimainkan anak-anak adalah permainan menjaga telur buaya. Permainan ini melatih kekompakan anak-anak, saling membantu menyelamatkan telur buayanya yang akan direbut oleh binatang lain.

Setiap 2 bulan sekali Khatulistiwa Berbagi mengadakan edutrip atau perjalanan edukasi dalam bentuk jalan-jalan ke tempat bersejarah. Hal ini bertujuan agar anak-anak didik mengenal sejarah yang ada di kota Pontianak dan mengetahui tentang berbagai hal yang ada di kota tempat mereka berada. Beberapa tempat yang sudah dikunjungi oleh anak-anak didik seperti museum Kalimantan Barat, Hanggar Landasan Udara Angkatan Udara dan juga Kapal Perang Angkatan Laut, dalam rangka menambah wawasan dan semangat peserta didik. Setiap bulan ramadhan diadakan pesantren kilat.

Pembelajaran yang diterapkan pada anak usia dini seperti mengenal huruf abjad, kemudian merangkainya menjadi sebuah kata. Anak-anak juga diajari angka, kemudian dilanjutkan dengan penambahan, 
pengurangan dan pembagian. Adapun anakanak sekolah tingkat dasar sampai menengah pertama, disesuaikan dengan kurikulum sekolah.

Di Khatulistiwa Berbagi diajarkan juga pendidikan agama dan akhlak khususnya mereka yang beragama Islam. pembelajaran mulai dari iqra sampai pada al-Quran. Selanjutnya anak-anak yang sudah lancar mengaji mulai menghapal surat-surat pendek. Pembelajaran akhlak diberikan kepada anak-anak dalam rangka membentuk perilaku yang sesuai dengan tuntunan agama dan harapan masyarakat pada umumnya. Selain pendidikan umum, agama dan akhlak, di Khatulistiwa Berbagi pendidikan karakter juga diutamakan, anak-anak diajari bagaimana hidup sehat dengan membiasakan mereka membuang sampah pada tempatnya, mengajari mencuci tangan yang benar, mengolah sampah, dan lain-lain.

Dari paparan di atas memperlihatkan bahwa manajemen dakwah sekolah informal Khatulistiwa Berbagi telah mengedepankan pada problem solvin. ${ }^{11}$ Untuk mengembangkan strategi problem solvin terlebih dahulu mereka mencari informasi mengenai kondisi anak-anak yang berkenaan

11 RB. Khatib Pahlawan Kayo, 2007, Manajemen Dakwah Dari Dakwah Konvensional Menuju Dakwah Profesional, Jakarta: Amzah, hlm. 31. dengan masalah internal, hambatan dan tantangan serta faktor pendukung yang dapat dijadikn potensi dan sumber pemecahan masalah anak-anak di lapangan.

Manajemen dakwah sekolah informal Khatulistiwa Berbagi sudah menerapkan manajemen modern, dimana mereka sangat memperhatikan Sumber Daya Manusia (SDM) yang mereka miliki, dan menugaskannya sesuai keahlian masingmasing. Mereka ini berusaha melakukan rekayasa sosial ${ }^{12}$ dalam bentuk terorganisir sesuai dengan firman Allah dalam QS AlImran: 104: "Hendaklah di antara kalian ada umat yang menyeru kepada kebaikan dan mencegah kemungkaran. Mereka itulah orang-orang yang beruntung".

Jumlah anak-anak didik mereka dapat dilacak baik yang aktif maupun yang jarang datang beserta persoalan masingmasing, bahkan kelebihan dan kekurangan individu setiap anak juga diketahui oleh guru. Kurikulum disesuaikan dengan kebutuhan murid, pembelajaran berjalan secara dialogis karena dilakukan secara khalaqah. Pembelajaran dievaluasi setiap anak-anak habis semester, hasil dari sekolah "asal" anak-anak diminta oleh kakak-kakak

12 Muhammad Munir dan Wahyu Ilaihi, 2009, Manajemen Dakwah, Jakarta: Rahmat Semesta, hlm. 270. 
atau guru di Khatulistiwa Berbagi untuk dievaluasi pada soal apa saja anak-anak mengalami masalah.

Proses belajar mengajar ini akan dievaluasi oleh pengurus dan kakak-kakak yang mengajar setiap sebulan sekali untuk melihat dan membahas segala persoalan yang timbul dalam proses pembelajaran. Apabila ada anak yang bermasalah, mereka akan menyelidiki apa masalah yang dihadapi anak didik mereka. boleh dikata mereka sangat mengenal anak-anak sebagai mad'u dakwahnya.

Keberhasilan proses belajar mengajar ini tidak terlepas dari faktor pendukung yakni keinginan anak-anak yang begitu kuat untuk belajar. Walaupun di antar mereka ada yang bekerja sebagai pengamen dan penjual Koran. Ini membuktikan bahwa anak-anak sudah belajar memenej waktu mereka antara bekerja dan belajar. Anak bekerja dianggap sebagai eksploitasi anak tetapi keadaan yang mengharuskan mereka untuk terlibat dalam meringankan beban keluarga mereka. Orang tua mereka adalah pemulung, pengamen, penjual Koran, buruh cuci dan pekerja kuli atau buruh lainnya. Mereka sangat "ringan tangan" dalam membantu orang tua. Ini terlihat sewaktu peneliti meminta mereka menulis sifat mereka yang baik, sebagian besar menjawab suka membantu orang tua.

\section{Dakwah Halaqah Khatulistiwa Berbagi}

Dakwah halaqah adalah dakwah dalam lingkaran terbatas atau kelompok. Dakwah halaqah telah dilakukan Rasulullah saw di rumah Arqam bin Abi Arqam dan dikenal sebagai lembaga pendidikan Islam pertama dalam sejarah Islam, lembaga ini dikenal dengan nama Dar-al-Arqam. ${ }^{13}$ Dar al Arqam bertujuan mengajari sahabat menulis, membaca dan menghafal al-Quran.

Khatulistiwa Berbagi menerapkan dakwah halaqah dengan cara mengklasifikasikan kebutuhan peserta didik berdasarkan tingkat pendidikan mereka. Mulai dari Pendidikan Anak Usia Dini (PAUD), Taman Kanak-kanak (TK), Sekolah Dasar (SD) sampai Sekolah Menengah Pertama (SMP).

Anak-anak PAUD dan TK diajari mengenal huruf alfabeth, berhitung, mengaji dan bahasa Inggris dengan cara bernyanyi. Anak-anak SD dan SMP diajari sesuai dengan kurikulum di sekolah. Anak-anak juga diajak berinteraksi dengan anak-anak

${ }^{13}$ Musyrifah Sunanto, 2007, Sejarah Islam Klasik Perkembangan Ilmu Pengetahuan Islam, Jakarta: Kencana, hlm. 16. Lihat juga Patmawati, 2014, "Sejarah Dakwah Rasulullah di Mekah dan Madinah" dalam jurnal Al-Hikmah, Vol. VIII Edisi 2. hlm. 6. 
yang lain, kakak-kakak mereka (pengajar), dan lingkungannya. Interaksi yang berjalan lancar akan mempengaruhi tujuan pembelajaran tercapai, di mana anak-anak akan mendapatkan pengalaman yang bermakna dalam hidup. Menurut Vigotsky dalam Sofia Hartati dikutif oleh Yafandi dkk., mengatakan bahwa "pengalaman interaksi sosial merupakan hal yang penting bagi perkembangan proses berpikir anak." ${ }^{14}$

Keberhasilan kakak-kakak dari sekolah informal Khatulistiwa Berbagi dalam mendidik anak-anak terbukti dari tidak adanya lagi anak-anak yang tidak naik kelas. Bukti berikutnya sewaktu peneliti dan kawan-kawan mengadakan pengabdian masyarakat di wilayah Waduk Permai, di mana sasaran pengabdian tersebut adalah anak-anak yang kebetulan juga peserta didik sekolah informal Khatulistiwa Berbagi. Sewaktu salah satu pengabdi yakni Nurmi AR. membahas mengenai ciptaan Tuhan dengan visual dan demonstratif sambil menggunakan bahasa Inggris. Anak-anak Waduk sangat mudah memahami maksud dan arahan yang diberikan ke mereka ${ }^{15}$. Hal ini tidak terlepas dari kosa-kata bahasa

$14 \quad$ Yapandi dkk., 2017, Nilai-nilai Multikultural Pada Anak Usia Dini (Pemberdayaan Guru Taman Kanak-kanak di Kota Pontianak), Pontianak: IAIN Pontianak Press, hlm. 15.

${ }^{15}$ Patmawati, Op. Cit., hlm. 216.
Inggris yang sudah banyak dikuasai anakanak, berkat pendidikan bahasa Inggris yang mereka peroleh dari Khatulistiwa Berbagi.

Anak-anak Khatulistiwa Berbagi selain diajari pengetahuan seperti yang telah disebutkan di atas, mereka juga diperkenalkan dengan lingkungannya atau dikenal dengan dakwah ekologi, kegiatan ini dilakukan sekali dalam seminggu, setiap hari sabtu. Anak-anak diarahkan untuk mencintai dan merawat lingkunga dengan cara yang sangat sederhana seperti membuang sampah di tempatnya, memilah sampah organik diolah menjadi pupuk dan non organik seperti aqua gelas akan dijadikan wadah untuk menanam dan bermain, membersihkan lingkungan dan menanam sayur-sayuran serta tanaman lainnya.

Dakwah ekologi ini dilakukan supaya anak-anak Khatulistiwa Berbagi memahami alam semesta yang terdiri dari tiga hal yang saling berkaitan yaitu antara Tuhan, manusia sebagai makhluk yang harus menjaga keseimbangan di alam semesta ini, dan alam itu sendiri sebagai ciptaan Tuhan yang berjalan sesuai dengan sunnahnya. Oleh karena itu terjadi relasi antara Tuhan, manusia dan Alam. ${ }^{16}$

\footnotetext{
16 Patmawati dan Besse Wahida, 2018, Konsep Ketauhidan Dalam Naskah Lontara Attorioloang ri Wajo, Pontianak: IAIN Pontianak Press, hlm. 195.
} 
Tuhan, Manusia dan Alam

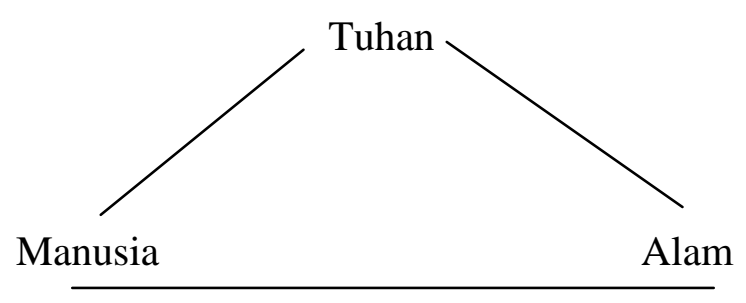

Harmonisasi relasi antara Tuhan, alam semesta, dan manusia merupakan kunci untuk menjaga kehidupan di muka bumi termasuk dalam menjaga makhluknya atau ciptaannya yakni manusia itu sendiri bersama alam sekitarnya. Menurut Yusuf Qardhawi dikutip oleh Muhammad Rahmat Effendi, bahwa tiga sudut segitiga itu dapat dipaparkan dalam tujuan hidup manusia, yaitu untuk mengabdi kepada Tuhan sesuai dengan tugas manusia di muka bumi ini sebagai khalifatullah fil ardhi), dan untuk membangun peradaban yang etis sesuai dengan kehendak Tuhan. ${ }^{17}$

Sri Sultan Hamengku Buwono X mengatakan bahwa hubungan harmonis dengan alam akan bermuara pada pembentukan insane kamil, manusia paripurna yang sudah sampai pada tataran "kesempurnaan" yang memiliki ciri-ciri harmonis lahir-batin, jiwa-raga, intelektual-

17 Muhammad Rahmat Effendi, 2017, "Model Konservasi Hutan Berbasis Agama Pada Masyarakat Adat Kampung Dukuh-Garut-Jawa Barat", Makalahlm. hlm. 11. spritual, yang akan melahirkan nilai-nilai humanism. Karena itu, tanpa adanya hablu minallah hubungan kemanusiaan akan cenderung semu, munafik dan eksploitatif. ${ }^{18}$

Pendidikan karakter merupakan rancangan pembejaran yang terprogram yang diberikan kepada anak-anak Khatulistiwa Berbagi. Sistem pembelajarannya dengan cara praktek langsung oleh para kakak-kakak Khatulistiwa Berbagi dalam bersikap menghadapi anak-anak. Berdasarkan pengamatan peneliti, kakak yang mengajari mereka, setelah pelajaran selesai akan memeluk setiap anak yang pamit pulang tanpa dibarengi rasa kikuk dan risih. Pelukan inilah yang membuat anakanak merasa diterima dan disayang, sehingga mereka menganggap bahwa Khatulistiwa Berbagi bukan saja sebagai tempat belajar tetapi juga untuk mendapatkan kasih dan menabur kasih. Kakak-kakak mereka di Khatulistiwa Berbagi bukan hanya sebagai pendidik tetapi juga $u s w a h^{19}$ atau teladan yang akan mereka panuti dalam bertingkah laku. Pelukan yang

${ }^{18}$ Nasruddin Anshoriy dan Sudarsono, 2008, Kearifan Lingkungan Dalam Perspektif Budaya Jawa, Jakarta: Obor, hlm. x.

19 Santa Rusmalita, 2017, "Internalisasi Nilai-nilai Dakwah Pada Anak Usia Dini di Taman Kanak Islam Terpadu (TKIT) Alkarimah", dalam jurnal Al-Hikmah, Vol. XI Edisi 2, Desember, hlm. 182. 
awalnya adalah sebuah kelakuan yang dirancang dengan sengaja, tetapi lamakelamaan akan menjadi kebiasaan dan bahkan menjai akhlak seluruh komponen yang ada di Khatulistiwa Berbagi.

\section{Mitra Dakwah Khatulistiwa Berbagi}

Khatulistiwa Berbagi sebagai sekolah informal yang independen dalam menjalankan program. Tetapi bukan berarti mereka menutup diri dari bantuan masyarakat yang tergerak dalam membantu anak-anak didik, seperti bantuan dari yayasan Munzalan Mubarakah dalam mengajari anak-anak agama dan akhlak karena para pengajar di Khatulistiwa Berbagi berlatar pendidikan umum. Ustas dari Munzalan Mubarakah ini yang mengajar setiap hari jumat. Dalam hal mengaji, anak-anak yang tinggal di wilayah Waduk Permai sebagian besar sudah bisa mengaji karena selain pelajaran agama yang didapatkan di Khatulistiwa Berbagi, mereka juga mengaji di surau Ikhwanul Muslimin yang berada di Waduk Permai setiap habis magrib, diajar oleh bapak Mulana.

Mitra Khatulistiwa Berbagi yang berasal dari perguruan tinggi di antaranya Jurusan Bimbingan Konseling Islam dan Manajemen Dakwah Fakultas Ushuluddin Adab dan Dakwah Institut Agama Islam
Negeri Pontianak. Bentuk bantuan mereka adalah melibatkan mahasiswa mengajari anak-anak, bantuan sarana dan prasarana, baju pantas pakai, Sembilan bahan pokok (sembako), dan buka puasa bersama.

Bantuan dari Sekolah Tinggi Akutansi Negara (STAN) dalam bentuk kunjungan mahasiswa STAN beserta ketua Senat mereka. Mereka mengajak anak-anak bermain seperti permainan Rumah Kelinci. Anak-anak dibagi menjadi dua kelompok sesuai dengan ketentuan umur. Kelompok pertama yaitu kelompok yang berumur 1012 tahun ke atas, sedangkan kelompok yang kedua yakni PAUD, TK dan SD di bawah usia 10 tahun.setelah permainan selesai mreka membuat lingkaran besar dan makan sore bersama-sama yang mana konsumsinya disiapkan oleh mahasiswa STAN Pontianak. Kemudian foto bersama dan pemberian hadiah oleh ketua Senat mahasiswa sebagai simbol.

Khatulistiwa Berbagi mendapatkan bantuan juga dari Dinas Kesehatan dalam rangka melaksanakan khitanan massal terhadap anak-anak didik. Anak-anak yang sudah dikhitan diberikan sarung atau mukenah. 


\section{KESIMPULAN}

Manajemen dakwah halaqah ini dilakukan oleh Khatulistiwa Berbagi dalam mendidik anak-anak pemulung yang ada di Waduk Permai, Kota Pontianak. Kegiatan dakwah halaqah melalui pendidikan pada anak-anak pemulung dapat dilaksanakan dengan secara terorganisir. Secara substansi, manajemen dakwah halaqah telah berhasil menumbuhkan semangat keagamaan, kemandirian sikap, kekompakan anak-anak dan kecintaan mereka terhadap ilmu pengetahuan umum dan agama Islam. Pelaksanaan kegiatan dakwah halaqah pada anak-anak pemulung Waduk Permai juga telah mampu memberikan semangat dan perhatian dari para pemerhati dakwah Islam di dunia kampus khususnya IAIN Pontianak sebagai kampus negeri yang berorietasi agama.

\section{DAFTAR PUSTAKA}

Alvin Toffler. (1989). Kejutan Masa Depan, Jakarta: Pantja Simpati

Deddy Mulyana. (2008). Metodologi Penelitian Kualitatif Paradigma Baru Ilmu Komunikasi dan Ilmu Sosial Lainnya, Bandung: Remaja Rosdakarya

Harjani Hefni (2014). Komunikasi Islam, Pontianak: IAIN Pontianak Press
Jauhar Fuad dkk. (2014). "Pemberdayaan Anak Jalanan Berbasis Musala di Kabupaten Ngadirejo Kota Kediri, dalam Kompilasi Hasil Penelitian Aksi Partisipatoris, Zidal Huda (penyusun), Jakarta: Direktorat Perguruan Tinggi Islam, Direktorat Jenderal Pendidikan Islam dan Kementerian Agama RI

Laporan tugas mata kuliah Manajemen Dakwah jurusan Bimbingan Konseling Islam semester IV tahun 2015.

Muh. Ishaq Samad. (2013). "Manajemen Dakwah Jejaring Dalam Pemberdayaan Masyarakat: Studi Manajemen Networking Learning Assistance Program For Islamic School (LAPIS)", dalam Jurnal Diskursus Islam, vol. 1, no. 1, April, Program Pascasarjana UIN Alauddin Makassar.

Muhammad Munir dan Wahyu Ilaihi. (2009). Manajemen Dakwah, Jakarta: Rahmat Semesta

Muhammad Rahmat Effendi. (2017). "Model Konservasi Hutan Berbasis Agama Pada Masyarakat Adat Kampung Dukuh-Garut-Jawa Barat", Makalah.

Musyrifah Sunanto. (2007). Sejarah Islam Klasik Perkembangan Ilmu Pengetahuan Islam, Jakarta: Kencana.

Nasruddin Anshoriy dan Sudarsono. (2008). Kearifan Lingkungan Dalam 
Perspektif Budaya Jawa, Jakarta: Obor.

Patmawati. (2014). "Sejarah Dakwah Rasulullah di Mekah dan Madinah" dalam jurnal Al-Hikmah, Vol. VIII Edisi 2

dkk., (2017). "Penggunaan Wasilah Dakwah Terhadap Anakanak Pemulung Waduk Permai”, dalam jurnal Al-Hikmah, Vol. XI Edisi 2.

- dan Besse Wahida. (2018). Konsep Ketauhidan Dalam Naskah Lontara Attorioloang ri Wajo, Pontianak: IAIN Pontianak Press.

RB. Khatib Pahlawan Kayo. (2007). Manajemen Dakwah Dari Dakwah Konvensional Menuju Dakwah Profesional, Jakarta: Amzah.

Samsul Munir Amin. (2009). Ilmu Dakwah, Jakarta: Amzah.

Santa Rusmalita. (2017). "Internalisasi

Nilai-nilai Dakwah Pada Anak Usia Dini di Taman Kanak Islam Terpadu (TKIT) Alkarimah", dalam jurnal Al-Hikmah, Vol. XI Edisi 2, Desember.

Soiman. (2017). "Dakwah Islam Untuk Masyarakat Marjinal Perkotaan" dalam Prosiding Seminar Nasional Manajemen Dakwah IAIN Pontianak dengan tema Revitalisasi Dakwah Pinggiran: Penguatan Profesionalitas Dai Infrastruktur Dakwah, Pontianak: IAIN Pontianak Press.
Yapandi dkk., (2017). Nilai-nilai Multikultural Pada Anak Usia Dini (Pemberdayaan Guru Taman Kanak-kanak di Kota Pontianak), Pontianak: IAIN Pontianak Press

Zuly Qodir. (2015). “Kontestasi Penyiaran Agama di Ruang Publik: Relasi Kristen dan Islam di Kota Jayapura", dalam jurnal Harmoni Vol.14 no. 1 Januari-April. 
AL-HIKMAH: Jurnal Dakwah, Volume 13, Nomor 1, Tahun 2019 [P. 061-076]

Lembaga Penelitian dan Pengabdian Kepada Masyarakat \& Fakultas Ushuluddin, Adab dan Dakwah (FUAD) IAIN Pontianak لl. Letjen. Saeprapto, No. IS Pontianak, Kalimantan Barat 78121 Phone: (0561) 734170 Mobile: 085741561121 